\title{
Successful Treatment of South American Rattlesnake (Crotalus durissus terrificus) Envenomation with Crotalidae Polyvalent Immune Fab (CroFab $\left.{ }^{\text {TM}}\right)$
}

\author{
Michael J. Lynch • Seth C. Ritter • Robert D. Cannon
}

Published online: 24 July 2010

(C) American College of Medical Toxicology 2010

\section{Introduction}

Crotalus durissus subspecies account for roughly $10 \%$ of snake envenomations in Brazil where the snake is native [1]. The venom of the C. durissus terrificus species has been found to be neurotoxic, myotoxic, and hemotoxic [1]. However, Medline search revealed no cases of envenomation reported in North America. No human data were found regarding treatment of this envenomation with Crotalidae polyvalent immune Fab (CroFab ${ }^{\mathrm{TM}}$ ), the most widely used and available commercial antivenom for Crotalus envenomation in the USA. We report the first documented C. durissus terrificus envenomation in North America and the first successful use of $\mathrm{CroFab}^{\mathrm{TM}}$ for a patient envenomated by this species.

\section{Case Report}

A 36-year-old man presented to the Emergency Department (ED) within $1 \mathrm{~h}$ of a bite to his left index finger by his pet snake, identified as a South American rattlesnake $(C$. durissus terrificus). The patient complained of 10/10 severe, sharp pain that was worse with movement. He also complained of numbness and tingling in his left arm

\section{J. Lynch $(\bowtie) \cdot$ R. D. Cannon}

Division of Medical Toxicology, Department of Emergency

Medicine, University of Pittsburgh Medical Center,

DL-45, 200 Lothrop St.,

Pittsburgh, PA 15213, USA

e-mail: lyncmj@upmc.edu

S. C. Ritter

University of Pittsburgh School of Medicine,

Pittsburgh, PA, USA as well as perioral paresthesias. He reported mild diplopia and ataxia. Presenting vital signs were temperature $36.7^{\circ}$ orally, pulse 110 beats per minute, respiratory rate 18 breaths per minute, blood pressure $153 / 76 \mathrm{mmHg}$, and oxygen saturation $98 \%$ on room air. The patient was awake, alert, and oriented. A single puncture wound was noted on the lateral aspect of the patient's index finger. Moderate swelling and erythema were noted at the site of the bite extending to his distal forearm. The swollen areas remained soft with intact sensation and pulses. Despite his neurologic symptoms, the patient had normal cranial nerve and cerebellar examinations.

The patient's early neurologic symptoms and progressive objective tissue injury were consistent with moderate toxicity. Since antivenom specific to this species was not available and a literature review indicated a scientific basis for treatment with $\mathrm{CroFab}^{\mathrm{TM}}$, therapy was initiated with six vials of $\mathrm{CroFab}^{\mathrm{TM}}$ administered intravenously (IV) and pain was controlled with fentanyl IV. The patient's arm was immobilized and elevated. Basic metabolic panel, complete blood count, fibrinogen, and coagulation studies obtained upon arrival and sent prior to the administration of $\mathrm{CroFab}^{\mathrm{TM}}$ were all within the normal range (Table 1). After the first dose of $\mathrm{CroFab}^{\mathrm{TM}}$, symptoms were no longer progressing, but repeat fibrinogen was $104 \mathrm{mg} / \mathrm{dL}$; PT was $15.9 \mathrm{~s}$. Another six vials of $\mathrm{CroFab}^{\mathrm{TM}}$ were given IV to gain control of mild hypofibrinogenemia. Following the second loading dose, repeat fibrinogen was $153 \mathrm{mg} / \mathrm{dL}$. The patient was admitted for observation, frequent neurologic checks, and maintenance therapy consisting of two vials of $\mathrm{CroFab}^{\mathrm{TM}}$ every $6 \mathrm{~h}$ for three doses. The patient's pain improved, and his neurologic symptoms resolved over the course of several hours. Fibrinogen prior to discharge was $267 \mathrm{mg} / \mathrm{dL}$, and PT had normalized (Table 1). CBC and platelets were normal throughout (Table 1). Maximum CPK 
Table 1 Serial coagulation studies and fibrinogen levels following envenomation and treatment with $\mathrm{CroFab}^{\mathrm{TM}}$

\begin{tabular}{lccccc}
\hline & Presentation & After first loading dose & After second loading dose & Discharge & Day7 \\
\hline Platelets $\left(\times 10^{9} / \mathrm{L}\right)$ & $261(156-369)$ & 265 & 269 & 257 & 263 \\
PT(s) & $14.2(11.6-14.3)$ & 15.9 & 14.7 & 13.9 & 17.8 \\
Fibrinogen $(\mathrm{mg} / \mathrm{dL})$ & $249(205-508)$ & 104 & 153 & 297 \\
\hline
\end{tabular}

was $1,085 \mathrm{IU} / \mathrm{L}(0-200)$. Repeat labs 7 days after envenomation and 5 days after discharge exhibited partial hypofibrinogenemic recurrence with fibrinogen level of $53 \mathrm{mg} / \mathrm{dL}$. Otherwise, the patient improved. Therefore, he was advised to maintain fall and bleeding precautions. No further antivenom was administered. Repeat labs, 3 days later, showed fibrinogen $156 \mathrm{mg} / \mathrm{dL}$. The patient's extremity pain and swelling resolved over the following weeks with no long-term sequelae.

\section{Discussion}

In the USA, two commercially available FDA licensed antivenoms have been available for treatment of native pit viper envenomations. Antivenin (Crotalidae) Polyvalent (ACP) is a whole immunoglobulin of equine origin derived from the venom of the South American rattlesnake $(C$. durissus terrificus), fer-de-lance (Bothrops atrox), eastern diamondback rattlesnake (Crotalus adamanteus), and western diamondback rattlesnake (Crotalus atrox). Ovinederived Crotaline Polyvalent Immune Fab Antivenom $\left(\mathrm{CroFab}^{\mathrm{TM}}\right)$, derived from the venoms of eastern diamondback rattlesnake (C. adamanteus), western diamondback rattlesnake (C. atrox), Mojave rattlesnake (Crotalus scutulatus), and cottonmouth (Agkistrodon piscivorus), has been approved in the USA since late 2000. In recent years, CroFab ${ }^{\mathrm{TM}}$ has largely replaced ACP due to decreasing supply of ACP and fewer acute and delayed hypersensitivity reactions associated with $\mathrm{CroFab}^{\mathrm{TM}}$ [2-4]. In this patient, ACP would have been the preferred treatment given its specificity for $C$. durissus terrificus; however, ACP is no longer available at our facility, the local zoo, or other local research facilities. Therefore, ACP could not be rapidly obtained.

A relative disadvantage of $\mathrm{CroFab}^{\mathrm{TM}}$ is the recurrence phenomenon described by Boyer et al. referring to rebound worsening of coagulation studies in the days following successful treatment with $\mathrm{CroFab}^{\mathrm{TM}}$ due to its shorter halflife as compared to ACP [5]. This patient did exhibit recurrence of modest hypofibrinogenemia which was corrected without further treatment. Although the hypofibrinogenemia was relatively mild, it lends support to our hypothesis that the antivenom provided some initial benefit by normalizing fibrinogen levels prior to discharge. Additional antivenom was not administered due to the minor nature of laboratory abnormalities and previously reported resistance to repeat dosing of $\mathrm{CroFab}^{\mathrm{TM}}$ for the treatment of recurrence [4].

The venom of $C$. durissus terrificus is made up of many active enzymes. Specific antivenom for this species is in use in its indigenous locations, and ACP does contain antibodies to $C$. durissus terrificus. However, neither of these products was immediately available at our institution nor could they be obtained from outside sources in a timely fashion. A CroFab ${ }^{\mathrm{TM}}$ supply is maintained in our pharmacy for the treatment of local Crotalid envenomations. Therefore, a literature search to determine potential effectiveness of its administration for the treatment of this envenomation was performed. Crotoxin, a neurotoxic phospholipase $\mathrm{A}_{2}$ found in $C$. durissus terrificus venom, is similar both in molecular weight and toxic effect to Mojave toxin, a component of Mojave rattlesnake (C. sculatus scutulatus) venom [1, 6]. Antiserum raised against crotoxin has been shown to neutralize Mojave toxin. One study of mice injected with a premixed solution of $\mathrm{CroFab}^{\mathrm{TM}}$ and $C$. durissus terrificus venom showed a significant survival benefit compared to mice injected with venom alone [7]. These findings of structural similarity and apparent neutralization in an animal model provided a scientific basis for the use of CroFab ${ }^{\mathrm{TM}}$, which contains antibodies to Mojave toxin, to treat envenomation by the South American rattlesnake [6]. Based upon these results, it was felt that $\mathrm{CroFab}^{\mathrm{TM}}$ administration was appropriate in the absence of more specific antivenom. While limited in vitro and animal studies suggest benefit of treatment, to our knowledge, it has never been reported following human envenomation.

\section{Conclusion}

Treatment with $\mathrm{CroFab}^{\mathrm{TM}}$ was beneficial following envenomation by $C$. durissus terrificus in this case. Previous animal and in vitro studies provide further support for its potential benefit. The proposed mechanism for its utility is activity against crotoxin which is structurally similar to Mojave toxin. Further research is required to prove its effect in human envenomation. 


\section{References}

1. Sano-Martins IS, Tomy SC, Campolina D, Dias MB, de Castro SC, de Sousa-e-Silva MC, Amaral CF et al (2001) Coagulopathy following lethal and non-lethal envenoming of humans by the South American rattlesnake (Crotalus durissus) in Brazil. QJM 94(10):551-559

2. Dart RC, Seifert SA, Boyer LV, Clark RF, Hall E, McKinney P, McNally J et al (2001) A randomized multicenter trial of cpolyvalent immune Fab (ovine) antivenom for the treatment for crotaline snakebite in the United States. Arch Intern Med 161(16):2030-2036

3. Jurkovich GJ, Luterman A, McCullar K, Ramenofsky ML, Curreri PW (1988) Complications of Crotalidae antivenin therapy. J Trauma 28(7):1032-1037

4. Ruha AM, Curry SC, Beuhler M, Katz K, Brooks DE, Graeme KA, Wallace $\mathrm{K}$ et al (2002) Initial postmarketing experience with Crotalidae polyvalent immune Fab for treatment of rattlesnake envenomation. Ann Emerg Med 39(6):609615

5. Boyer LV, Seifert SA, Cain JS (2001) Recurrence phenomena after immunoglobulin therapy for snake envenomations: Part 2. Guidelines for clinical management with crotaline Fab antivenom. Ann Emerg Med 37(2):196-201

6. Gopalakrishnakone P, Hawgood BJ, Holbrooke SE, Marsh NA, Santana De Sa S, Tu AT (1980) Sites of action of Mojave toxin isolated from the venom of the Mojave rattlesnake. Br J Pharmacol 69(3):421-431

7. Richardson WH 3rd, Tanen DA, Tong TC, Betten DP, Carstairs SD, Williams SR, Cantrell FL et al (2005) Crotalidae polyvalent immune Fab (ovine) antivenom is effective in the neutralization of South American Viperidae venoms in a murine model. Ann Emerg Med 45(6):595-602 